Plant Tissue Cult. \& Biotech. 23(2): 211-219, 2013 (December)

$\overline{\text { PTC\&B }}$

\title{
In vitro Morphogenesis of Arabian Date Palm (Phoenix dactylifera L.)
}

\section{Md. Abul Kalam Azad ${ }^{*}$, Hasnatul Arefin ${ }^{1}$ and Md. Amzad Hossain ${ }^{1}$}

Department of Biotechnology and Genetic Engineering, Islamic University, Kushtia, Bangladesh

Key words: Arabian date palm, Phoenix dactylifera, In vitro morphogenesis, Juvenile leaf

\begin{abstract}
After inoculation of young leaves of date palm offshoot required about six months to complete the morphogenesis process. Fourteen weeks were required for embryogenic callus formation under continuous dark condition and nine weeks for shoot initiation (under $16 / 8 \mathrm{~h}$ light/dark). The highest number of explants (80\%) produced callus in modified MS containing $5 \mathrm{mg} / 1$ 2,4-D + $2 \mathrm{mg} / \mathrm{l}$ 2ip. Sixty per cent of explants produced callus in the modified medium containing $5 \mathrm{mg} / \mathrm{l}$ 2,4-D + $5 \mathrm{mg} / \mathrm{l}$ NAA. While only 50 per cent of the explants formed callus in the same medium when supplemented with only $5 \mathrm{mg} / 1$ 2,4-D. The induced calli were transferred to modified MS for shoot proliferation. A combination of two cytokines showed better performance than single ones in shoot induction. The highest percentage (70) of shoot developed in modified MS containing $2 \mathrm{mg} / \mathrm{l} \mathrm{BAP}+1 \mathrm{mg} / \mathrm{l} \mathrm{Kn}$. Forty per cent shoot induction was found in the same medium supplemented with $2 \mathrm{mg} / \mathrm{l}$ of BAP. Thirty per cent shoot formed in MS containing $1 \mathrm{mg} / \mathrm{l}$ of $\mathrm{Kn}$. The shoots were subcultured at threefour week intervals throughout culture duration.
\end{abstract}

\section{Introduction}

The Arabian date palm (Phoenix dactylifera L.) a diploid $(2 n=36)$ is an outbreeding perennial monocotyledon of the family Arecacea cultivated in North Africa and the Middle East. The date palm is a major fruit crop in most Arab countries (Loutfy and El-Juhany 2010) and the top ten producing countries were Egypt, Saudi Arabia, Iran, United Arab Emirates, Pakistan, Algeria, Sudan, Oman, Libya, and Tunisia (Kader and Hussein 2009). Due to its outbreeding and heterozygous nature, date palm progenies consist of approximately $50: 50$ male and female trees (Carpenter and Ream 1976). Conventional propagation is by

*Author for correspondence: <akazadbtge@hotmail.com>. ${ }^{1}$ Biotechnology Division, Bangladesh Sugarcane Research Institute, Ishurdi, Pabna, Bangladesh. 
offshoots making them slow to establish new plantations. In addition, seed propagated palms do not bear true to type due to heterozygosity and require up to seven years fruiting. The need for rapid and efficient vegetative propagation systems for elite genotypes has therefore become urgent.

Since 1970 intensive efforts have been undertaken for large scale micropropagation of date palm using somatic embryogenesis and organogenesis (Drira 1983, Drira and Benbadis 1985, Tisserat 1979, El Hadrami et al. 1998). Somatic embryogenesis proved to be a quick and efficient method for large scale propagation and highly useful for breeding programs (El Hadrami et al. 1998), because the production of selected healthy female plants which are disease and pest-free, genetically uniform and true to type that are produced within three four years, to avoid seasonal effect plants are multiplied under controlled (laboratory and greenhouse) conditions round the year, when large scale production is required (Zaid and Wet 2002). Date palm fruits contain a variety of vitamins and minerals which have different physiological functions (El-Sohaimy and Hahez 2010).

In vitro improvement of date palm through somatic embryogenesis and their subsequent physiological and morphological responses have been the focus of recent study (Omar and Novak 1990, Sudhersan et al. 1993, El- Hadrami and Baaziz 1995, Zaid and Hughes 1995, Veramendi and Navarro 1996, 1997, AlKhayri 2001, 2002, 2003, Al-Khayri and Al-Bahrany 2001, Fki et al. 2003). Progress has been made in distinguishing embryogenic and non-embryogenic date palm calli based on peroxidase activity (Baaziz et al. 1994). Calli were usually initiated from the cut ends of the explants.

The objective of this study was to investigate the role of different concentrations and combinations of 2,4-D, NAA, 2ip, BAP and Kn to induce somatic embryogenesis and shoot initiation from juvenile leaf explants of date palm.

\section{Materials and Methods}

An efficient morphogenesis protocol has been developed through in vitro culture technique from juvenile leaves of offshoot of date palm were used in various combinations and concentrations of PGR in modified MS. This is the first report of in vitro date palm morphogenesis in Bangladesh. Offshoots were obtained from adult Arabian date palm cv. Ajwah growing in Bangladesh Sugarcane Research Institute (BSRI) date palm garden.

About $6-8 \mathrm{~cm}$ long leaf base was cut from the unexpanded leaf. These collected parts were first washed thoroughly in running tap water for 10 - 15 min, then they were cleaned with 5\% Savlon and 70\% ethyl-alcohol and rinsed 
with sterile double distilled water. Thereafter then they were cleaned with liquid detergent Tween $20(1 \% \mathrm{v} / \mathrm{v})$ for $5-10 \mathrm{~min}$ and rinsed with sterile double distilled water. Finally they were surface sterilized with $0.1 \% \mathrm{HgCl}_{2}$ (w/v) solution for $20 \mathrm{~min}$ and again washed well in sterile distilled water three - four times to remove all traces of $\mathrm{HgCl}_{2}$ (Badawy et al. 2005).

Surface sterilized juvenile leaves of $0.5-1 \mathrm{~cm}$ were aseptically inoculated on modified MS with different concentrations of 2,4-D (3, 5, 10, 20 and $40 \mathrm{mg} / \mathrm{l})$, in combination with 2,4-D + NAA $(3+3,5+5,10+10$ and $20+10 \mathrm{mg} / \mathrm{l})$ and 2,4-D + 2ip $(3+1,5+2,10+2$ and $20+3 \mathrm{mg} / \mathrm{l})$ for callusing (Othmani et al. 2009b, ElShiaty et al. 2004, Jain and Gupta 2005 and Taha et al. 2002). The primary callus obtained from the explants was subcultured in the same medium. MS without PGRs was also tested for the induction of embryogenic cells. Cultures were kept in darkness at $28 \pm 2^{\circ} \mathrm{C}$ and subcultured after every three - four weeks for 14 weeks under the same culture conditions until maturation. To promote proliferation, the entire expanding explants with resultant callus were transferred to modified MS supplemented with $0.1 \mathrm{mg} / 1$ 2,4-D and devoid of AC Once embryogenic culture mass increased they were maintained and proliferated by subculturing at three - four weeks intervals and incubated under the same conditions as for initiation (Othmanit et al. 2009a).

For shoot multiplication, embryogenic callus was transferred to modified MS supplemented with different concentrations of BAP and Kn separately (1, 2, 3, 4, and 5) and different combined concentrations of BAP $+\mathrm{Kn}(1+1,1+2,1+3,2+$ $1,2+2,2+3 \mathrm{mg} / \mathrm{l})$ and obtaining morphogenetic responses from calli, cultures were exposed to maintain at $28 \pm 2{ }^{0} \mathrm{C}$ under $16 \mathrm{~h}$ light and $8 \mathrm{~h}$ dark cycle for nine weeks. Lighting was provided using white cool fluorescent tubes of $40 \mu \mathrm{mol} / \mathrm{m}^{2} / \mathrm{s}$ light intensity. Roots were also produced above the condition for long time maintained (Junaid and Saeed 2009).

For all the above studies, modified MS contained 3\% (w/v) sucrose, $0.5 \mathrm{~g} / \mathrm{l}$ activated charcoal (AC), $10 \%$ coconut milk, $\mathrm{NaH}_{2} \mathrm{PO}_{4}(170 \mathrm{mg} / \mathrm{l})$, citrate $(100$ $\mathrm{mg} / \mathrm{l})$, biotin $(2 \mathrm{mg} / \mathrm{l})$ and were solidified with $0.7 \%$ agar. The $\mathrm{pH}$ of all media was adjusted to 5.7 prior to autoclaved at $121^{\circ} \mathrm{C}$ at 15 psi for $20 \mathrm{~min}$. Experiments were repeated at least three times and at least ten cultures were employed per treatment (Jain and Gupta 2005).

\section{Results and Discussion}

It was found that the highest percentage (50) of explant produced callus in modified MS supplemented with $5 \mathrm{mg} / \mathrm{l}$ 2,4-D in dark condition (Fig.1a). It was revealed that callus initiation started at $3 \mathrm{mg} / 1$ 2,4-D and reached the peack (50\%) at $5 \mathrm{mg} / \mathrm{l}$. After that it was gradually decreased up to $20 \mathrm{mg} / \mathrm{l}$, Moreover, no 
callus was initiated in the modified MS fortified with the concentration of 2,4-D (control and $40 \mathrm{mg} / \mathrm{l}$ ) (Table 1). Othmani et al. (2009b) and Aslam et al. (2009) found similar results in their research. After eight weeks, callus was maintained at low concentration of $1 \mathrm{mg} / 12.4-\mathrm{D}$ and kept in dark condition for proliferation of embryogenic callus. Roots also formed from the embryogenic callus within six weeks. (Othmani et al. 2009a, Zaid and Wet 2002 and Gueye et al. 2009).

The maximum embryogenic callus $(60 \%)$ was revealed in modified MS containing $5 \mathrm{mg} / \mathrm{l}$ 2,4-D + $5 \mathrm{mg} / \mathrm{l}$ NAA within 14 weeks in dark condition (Fig. $1 b)$. It was found that callus initiation started at $3 \mathrm{mg} / 12,4-\mathrm{D}+3 \mathrm{mg} / \mathrm{l} \mathrm{NAA}$ and reached the peack $(60 \%)$ at $5 \mathrm{mg} / \mathrm{l} 2,4-\mathrm{D}+5 \mathrm{mg} / \mathrm{l} \mathrm{NAA}$. After that it was gradually decreased up to $10 \mathrm{mg} / \mathrm{l} 2,4-\mathrm{D}+10 \mathrm{mg} / \mathrm{l} \mathrm{NAA}$, no callus was induced in the MS fortified with the concentration of 2,4-D + NAA (control and $20+10$ $\mathrm{mg} / \mathrm{l})$ (Table 1). Zaid and Wet (2002) were used high concentration of 2, 4-D (100 $\mathrm{mg} / \mathrm{l})$ for embryogenic callus. After eight weeks at low concentration of $1 \mathrm{mg} / \mathrm{l}$ 2,4-D + $1 \mathrm{mg} / \mathrm{l} \mathrm{NAA}$ were added in the modified MS in dark condition for proliferation of embryogenic callus and induction of roots (Othmani et al. 2009a and Al-Khalifah 2006).

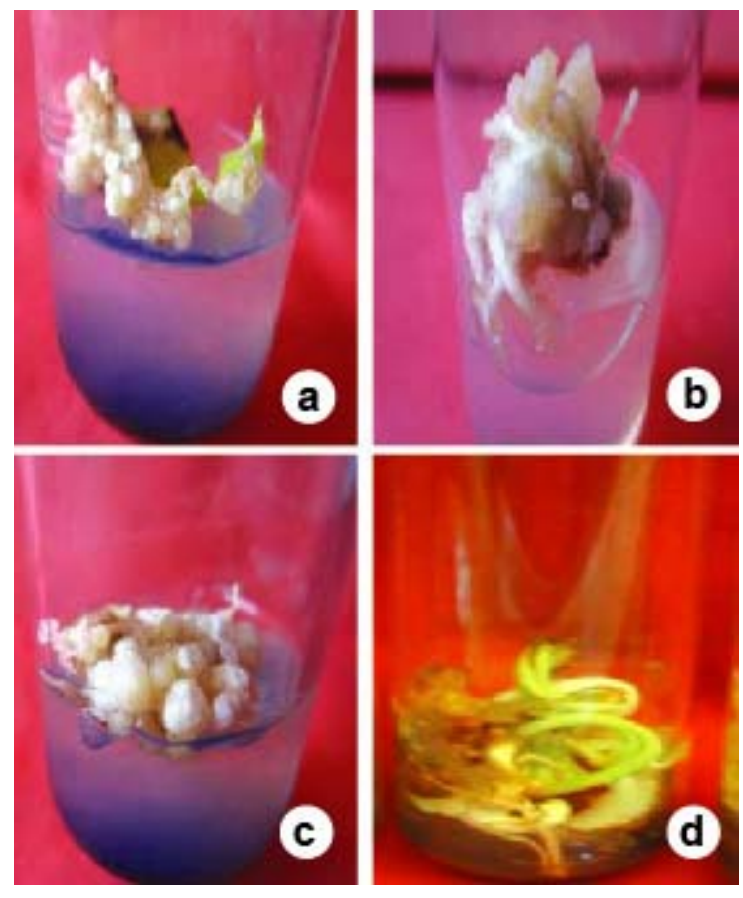

Fig. 1a-d. Morphogenesis in in vitro grown explants of a juvenile leaf offshoot a-c. Embryogenic Callus. d. Shoot induced from embryogenic callus. 
The best profuse callus (80\%) was found (Figs $1 \mathrm{~b}$ and c) in modified MS containing $5 \mathrm{mg} / \mathrm{l}$ 2,4-D $+2 \mathrm{mg} / \mathrm{l}$ 2ip within eight weeks in dark condition. It was also observed that callus initiation started at $3 \mathrm{mg} / 12,4-\mathrm{D}+1 \mathrm{mg} / \mathrm{l} 2 \mathrm{ip}$ and reached $80 \%$ at concentration $5 \mathrm{mg} / 12,4-\mathrm{D}+2 \mathrm{mg} / \mathrm{l} 2 \mathrm{ip}$. After that it gradually decreased up to $10 \mathrm{mg} / \mathrm{l} 2,4-\mathrm{D}+2 \mathrm{mg} / \mathrm{l} 2 \mathrm{ip}$, no callus was formed in the concentration of 2,4-D + 2ip (control and $20+3 \mathrm{mg} / \mathrm{l}$ ) (Table 1) (Bekheet et al. 2008, El-Shiaty et al. 2004 and Badawy et al. 2005). After eight weeks at low concentration of $0.5 \mathrm{mg} / 1$ 2,4-D + $0.1 \mathrm{mg} / 1$ 2ip were added in modified MS and kept in dark condition for proliferation of embryogenic callus. Roots were formed from embryogenic callus within six weeks. Therefore, It was revealed that $5 \mathrm{mg} / \mathrm{l} 2,4-\mathrm{D}+2 \mathrm{mg} / \mathrm{l} 2 \mathrm{ip}$ is the best performance for callus induction in above concentrations.

Table 1. Effect of different concentrations of 2,4-D, 2,4-D + NAA and 2,4-D + 2iP in modified MS on callus initiation.

\begin{tabular}{|c|c|c|c|c|c|}
\hline PGR & $\begin{array}{l}\text { PGR conc. } \\
(\mathrm{mg} / \mathrm{l})\end{array}$ & $\begin{array}{c}\text { Number of } \\
\text { explant } \\
\text { inoculated }\end{array}$ & $\begin{array}{c}\text { Weeks to } \\
\text { callus } \\
\text { initiation }\end{array}$ & $\begin{array}{l}\text { Degree of } \\
\text { callusing }\end{array}$ & $\begin{array}{c}\text { Callus } \\
\text { initiated } \\
(\%) \\
\end{array}$ \\
\hline \multirow[t]{6}{*}{$2,4-\mathrm{D}$} & Control & 1 & 14 & - & - \\
\hline & 3 & 20 & $"$ & ++ & 20 \\
\hline & 5 & 20 & $"$ & +++ & 50 \\
\hline & 10 & 20 & $"$ & ++ & 30 \\
\hline & 20 & 20 & $"$ & - & 10 \\
\hline & 40 & 20 & $"$ & - & - \\
\hline \multirow[t]{5}{*}{$2,4-\mathrm{D}+\mathrm{NAA}$} & Control & 1 & $"$ & - & - \\
\hline & $3+3$ & 20 & $"$ & ++ & 30 \\
\hline & $5+5$ & 20 & $"$ & +++ & 60 \\
\hline & $10+10$ & 20 & $"$ & ++ & 35 \\
\hline & $20+10$ & 20 & $"$ & - & - \\
\hline \multirow[t]{5}{*}{$2,4-\mathrm{D}+2 \mathrm{ip}$} & Control & 1 & $"$ & - & - \\
\hline & $3+1$ & 20 & $"$ & ++ & 35 \\
\hline & $5+2$ & 20 & $"$ & +++ & 80 \\
\hline & $10+2$ & 20 & $"$ & ++ & 40 \\
\hline & $20+3$ & 20 & $"$ & - & - \\
\hline
\end{tabular}

Degree of callusing: '-'means no response, ' + ' means slight callusing, ' ++ ' means medium callusing, ' +++ ' means profuse callusing.

The embryogenic calli derived from young leaves of offshoot were transferred to shoot induction medium (modified MS) supplemented with different concentrations of BAP and $\mathrm{Kn}$ alone and or in combination. The embryogenic calli were kept in 16 hrs light conditions. The highest percentage of shoots (70) were regenerated from embryogenic calli when cultured in modified MS containing $2 \mathrm{mg} / \mathrm{l} \mathrm{BAP}+1 \mathrm{mg} / \mathrm{l} \mathrm{Kn}$ (Fig. 1d). Forty per cent shoots were 
formed in modified MS containing only BAP @ $2 \mathrm{mg} / 1$ while only 30 per cent shoots were formed in the same medium containing $1 \mathrm{mg} / \mathrm{l} \mathrm{Kn}$ (Table 2). It was revealed that shoot induction percentage increased up to $2 \mathrm{mg} / \mathrm{l} \mathrm{BAP}$ and or up to $1 \mathrm{mg} / \mathrm{l} \mathrm{Kn}$, and declined the percentage of shoot formation beyond the above concentration. Therefore, it could be mentioned that the combined effect of different cytokinins showed better performance than single one for shoot induction from embryogenic calli (Aslam et al. 2009). Two cytokinin tested BAP was more active than $\mathrm{Kn}$ during multiple shoot formation. The superiority of BAP than Kn for multiple shoot formation was also demonstrated in other plants like Jetropha integerrima (Sujatha and Dhingra 1993), Sapium sebiferum (Siril and Dhar 1997), and Bombaxceiba (Chand and Singh 1999, 2004). Shoot multiplication rate decreased with increasing BAP concentrations up to $3 \mathrm{mg} / \mathrm{l}$. Similar effect was also found in many other plant tissue cultures (Jouira et al. 1998, Biroscikova et al. 2004, Junaid et al. 2007).

Table 2. Effect of different concentrations of BAP and $\mathrm{Kn}$ alone and in combination with modified MS on shoot induction from embryogenic callus.

\begin{tabular}{lcc}
\hline PGR & $\begin{array}{c}\text { PGR conc. } \\
(\mathrm{mg} / \mathrm{l})\end{array}$ & $\begin{array}{c}\text { Shoot formation } \\
(\%)\end{array}$ \\
\hline BAP & Control & - \\
& 1 & 10 \\
& 2 & 40 \\
& 3 & 10 \\
Kn & 4 & - \\
& 5 & - \\
& Control & - \\
& 1 & 30 \\
& 2 & 10 \\
BAP + Kn & 3 & - \\
& 4 & - \\
& 5 & - \\
& Control & - \\
& $1+1$ & 20 \\
& $1+2$ & - \\
& $1+3$ & - \\
& $2+1$ & 70 \\
\hline
\end{tabular}

'-' means no response.

Present study elucidated an efficient protocol for plant morphogenesis via embryogenesis of date palm and this will be helpful in conducting micropropagation. 


\section{Acknowledgements}

The authors gratefully acknowledge the help received from Dr. M A Samad Miah, Ex-Director General of Bangladesh Sugarcane Research Institute (BSRI), Ishurdi, Pabna for providing necessary laboratory facilities to carry out this piece of research. During the period his study leave, A K Azad was supported by a Ph.D. scholarship from the Bangladesh University Grants Commission (UGC).

\section{References}

AI-Khalifah NS (2006) Micropropagation and DNA fingerprinting of date palm trees of Saudi Arabia. Aariena Pub. 1: 5-15.

Al-Khayri JM (2001) Optimization of biotin and thiamine requirements for somatic embryogenesis of date palm (Phoenix dactylifera L.). In vitro Cell Dev. Biol. Plant. 37: 453-456.

Al-Khayri JM (2002) Growth, proline accumulation, and ion content in Nacl-stressed callus cultures of date palm (Phoenix dactylifera L.). In vitro Cell Dev. Biol. Plant. 38: 79-82.

Al-Khayri JM (2003) In vitro germination of somatic embryos in date palm: Effect of auxin concentration and strength of MS salts. Cur. Sci. 84: 101-104.

Al-Khayri JM and Al-Bahrany AM (2001) Silver nitrate and 2-isopentyladenine promote somatic embryogenesis in date palm (Phoenix dactylifera L.). J. Sci Horti. 89: 291-298.

Aslam J and Khan SA (2009) In vitro micropropagation of khalas' date palm (Phoenix dactylifera L.), an important fruit plant. J. Fruit Orna. Plant Res. 17: 15-27.

Badawy EM, Afaf MA, Habib AEB and Yosry GM (2005) Propagation of date palm (Phoenix dactylifera) plants by using tissue culture technique. Arab J. Biotech. 8: 343-354.

Baaziz M, Aissam F, Brakez Z, Bendiab K, Hadrami IE and Cheikh R (1994) Electrophoretic patterns of acid soluble proteins and active isoforms of peroxidase and polyphenoloxidase typifying calli and somatic embryos of two reputed date palm cultivars in Morocco. Euphytica 76: 159-168.

Bekheet SA, Taha HS, Hanafy MS and Solliman ME (2008) Morphogenesis of Sexual Embryos of Date Palm Cultured In vitro and early identification of sex type. J. Appl. Sci. Res. 4: 345-352.

Biroscikova MK, Spisakova, Liptak S and Pichler V (2004) Micropropagation of mature Wych elm (Ulmus glabra Huds.). Plant Cell Rep. 22: 640-644.

Carpenter JB and Ream CL (1976) Date palm breeding, a review. Date Grow Inst. Rep. 53: 23-33.

Chand S and Singh AJ (2004) In vitro shoot regeneration from cotyledonary node explants of a multipurpose leguminous tree, Pterocarpus marsupium roxb. In vitro Cell Dev. Biol. Plant. 40: 167-170. 
Chand S and Singh AJ (1999) In vitro propagation of Bombex ceiba L. (Silkcotton). Silvae. Genetics. 48: 313-317.

Drira N (1983) Multiplication végétative du palmier dattier (Phoenixdactylifera L.) par la culture in vitro de bourgeons axillaires et de feuilles qui en dérivent. C. R. Acad. Sci. 296: 1077-1082.

Drira N and Benbadis A (1985) Multiplication végétative du palmier dattier (Phoenix dactylifera L.) par réversion, en culture in vitro d'ébauches florales de pieds femelles adultes. J. Plant Physiol. 119: 227-612.

El-Hadrami I and Baaziz M (1995) Somatic embryogenesis and plant regeneration from shoot-tip explants in Phoenix dactylifera L. Biol. Plant. 37: 205-211.

El-Hadrami I, El Bellaj M, El Idrissi A, J'Aiti F, El Jaafari S and Daayf F (1998) Biotechnologie vegetables et amelioration du palmier dattier (phoenix dactylifera $\mathrm{L}$.) Pivot de l'agriculture oasienne Marocaine. Cah. Agric. 7: 463-468

El-Shiaty OH, El-Sharabasy SF and El-Kareim AHA (2004) Effect of some amino acids and biotin on callus and proliferation of date palm (Phoenix dactylifera L.) Sewy cultivar. Arab J. Biotech. 7: 265-272.

El-Sohaimy SA and Hafez EE (2010) Biochemical and nutritional characterizations of date palm fruits (Phoenix dactylifera L.). J. App. Sci. 6: 1060-2010.

Fki L, Masmoudi R, Drira N and Rival A (2003) An optimized protocol for plant regeneration from embryogenic suspension cultures of date palm (Phoenix dactylifera L.) cv. Deglet Nour. Plant Cell Rep. 21: 517-524.

Gueye B, Ahmed HS, Morcillo F, Borgel A, Sane D, Hilbert JL, Verdeil JL and Blervacq AS (2009) Callogenesis and rhizogenesis in date palm leaf segments: are there similarities between the two auxin-induced pathways?. Plant Cell Tiss. Org. Cult. 98: 47-58.

Jain SM and Gupta PK (2005) Protocols of somatic embryogenesis in woody plants. Springer (eds), The Netherland. pp. 309-320.

Jouira B, Hassairi JHA, Bigot C and Dorion N (1998) Adventitious shoot production from strips of stem in the Dutch elm hybrid 'Commelin': plantlet regeneration and neomycin sensitivity. Plant cell tiss. Org. Cult. 53: 153-160.

Junaid A and Saeed AK (2009) In vitro micropropagation of 'Khalas' date palm (Phoenix dactylifera L.), an important fruit plant. J. Fruit Orna. Plant Res. 17: 15-27.

Junaid A, Mujib A, Bhat MA, Sharma MP and Samaj J (2007) Somatic embryogenesis and plant regeneration in Catharanthus roseus. J. Biol. Plant. 51: 641-646.

Kader AA and Hussein AM (2009) Harvesting and Post-harvest handling of dates, International Center for Agricultural Research in the Dry Areas (ICARDA). Alepp. Syria. 4: 1-15

Loutfy I and El-Juhany (2010) Degradation of Date Palm Trees and Date Production in Arab Countries: Causes and Potential Rehabilitation. Aus. J. Basic Appl. Sci. 4: 39984010.

Omar MS and Novak FJ (1990) In vitro plant regeneration and ethyl-methane-sulphonate (EMS) uptake in somatic embryos of date palm (Phoenix dactylifera L.). Plant Cell Tiss. Org. Cult. 20: 185-190. 
Othmani A, Bayoudh C, Drira N, Marrakchi M and Trifi M (2009a) Somatic embryogenesis and plant regeneration in date palm Phoenix dactylifera L., cv. Boufeggous is significantly improved by fine chopping and partial desiccation of embryogenic callus. Plant Cell Tiss. Org. Cult. 97: 71-79.

Othmani A, Bayoudh C, Drira N, Marrakchi M and Trifi M (2009b) Regeneration and molecular analysis of date palm (Phoenix dactylifera L.) plantlets using RAPD markers. Afri. J. Biotech. 8: 813-820.

Siril EA and Dhar U (1997) Micropropagation of mature Chinese tallow tree (Sapium sebiferum Roxb.). Plant Cell Rep. 16: 637-640.

Sudhersan C, El-Nil A and Al-Baiz A (1993) Occurrence of direct somatic embryogenesis on the sword leaf of in vitro plantlets of Phoenix dactylifera L. cultivar Barhee. Cur. Sci. 65: 887-888.

Sujatha M and Dhingra M (1993) Rapid plant regeneration from various explants of Jetropha integerrima. Plant Cell Tiss. Org. Cult. 35: 293-296.

Taha HS, Bekheet SA and El-Bahr MK (2002) Alternative approach for micropropagation of the date palm c.v. Zaghlool. Arab J. Bio. 6: 103-112.

Tisserat B (1979) Propagation of date palm (Phoenix dactylifera L.) in vitro. J. Exp. Bot. 30: 1275-1283.

Veramendi J and Navarro L (1996) Influence of physical conditions of nutrient medium and sucrose on somatic embryogenesis of date palm. Plant Cell Tiss. Org. Cult. 45: 159-164.

Veramendi J and Navarro L (1997) Influence of explant sources of adult date palm (Phoenix dactylifera L.) on embryogenic callus formation. J. Hort. Sci. 72: 665-671.

Zaid A and Wet DPF (2002) Date palm propagation. In: Date palm cultivation. FAO Plant Production and Protection. Food and Agriculture Organization of the United Nations, Rome. pp. 73-105.

Zaid A and Hughes H (1995) Water loss and polyethylene glycol-mediated acclimatization of in vitro-grown seedlings of 5 cultivars of date palm (Phoenix dactylifera L.) plantlets. Plant Cell Rep. 14: 385-388. 